\title{
The Qualitative Analysis of Turkish Adult Education System in Terms of Management Processes
}

\author{
Bertan Akyol $^{1}$ \\ ${ }^{1}$ Faculty of Education, Department of Educational Sciences, Adnan Menderes University, Aydın, Turkey \\ Correspondence: Bertan Akyol, Faculty of Education, Department of Educational Sciences, Adnan Menderes \\ University, Aydın, Turkey. Tel: 90-505-810-0011. E-mail: bertanakyol@yahoo.com
}

Received: May 17, 2016

doi:10.5539/ies.v9n11p181
Accepted: June 20, $2016 \quad$ Online Published: October 27, 2016

URL: http://dx.doi.org/10.5539/ies.v9n11p181

\begin{abstract}
The aim of this study is to analyze the views of the administrators of public education centers in Turkey for the programs carried in their institutions in frame of the management processes which are decision-making, planning, organization, communication, coordination, affection and evaluation. For this purpose, 17 public education center administrators were interviewed. The responses that were taken have revealed that decisions are made by taking into account the needs of the trainees, the standards determined by Lifelong Learning General Directorate and the demands related to educational programs; planning is done according to reports of the commission and in frame of the criterions; for organization process, administrators fulfill all the essentials of organization process; in communication process, the administrators declare to take into consideration of the whole shareholders; for coordination process, the administrators declare that the centers experience problems especially about classrooms, trainers and material perform coordination activities in order to be able to meet these necessities; administrators use motivation techniques for both the trainees and the trainers; and lastly the administrators state that they use process evaluation and evaluate the trainees both during and at the end of the programs.
\end{abstract}

Keywords: adult education, public education, management processes

\section{Introduction}

Being an adult can be defined as biologically the age for reproduction, legally the age of being a major, socially playing grown-up roles, psychologically the age that the individual feels himself/herself as grown-up, takes the responsibility of managing his/her own life, feeling that he/she is ready to give his/her own decisions and get responsibilities. Adult education involves activities and programmes designed so as to meet the learning necessities and interests the individuals who are out of compulsory education age and whose main aim is not having education at a school will be in need of (Hamilton, 1992; Jarvis, 1987; UNESCO, 1985). The reasons necessitating adult education can be handled from different point of views. They can be given as: scientific and technological developments; obligations that economic and social improvements bring; the extend of mean human lifetime, decrease in the working hours; stunning progress in the fund of knowledge and technology, and thus the necessity for the acquisition of new information and abilities; professional mobility; the increase in the effects of communication and mass media, and the increase in the desire for harmony in international affairs (Duman, 2007). Within this context, it is a fact that in such a world where information goes out of date and becomes deficient immediately, every individual should benefit from adult education service continuously and improve himself/herself no matter what level he/she is in. That's why, adult education gradually becomes one of the most significant elements for the future of mankind and societies (Jarvis, 2010; Kowalski, 1998; Miser, 2002).

The necessities, interests and experiences of each individual are different from one another. Detecting the interests and necessities of the adult education participants is essential in preparing adult education programs. For this, the knowledge, aims, levels of achievement and attitudes of adult groups towards the learnt should be known and application programs should be determined following that (Davison, 1967). It is not possible to design adult education programs as standard programs just like it is in formal education because the content of the program and the methods and techniques to be used should be defined in advance as the content of the program is the necessities of the adults (Celep, 2003; Morgan, Ponticell, \& Gordon, 1998; Tight, 2002). The objective in adult education is to estimate not only the current necessities but also the new ones in accordance 
with the physical and social changes (Walklin, 1990). Today these changes are either not realized or realized only if they are made obvious. That's why, it is necessary to detect educational necessities at national level; however, it is also necessary to conduct it from a central unit based on economic and social indicators. The institution responsible for this in Turkey is General Directorate of Lifelong Learning at Ministry of National Education. At local level, the responsible institutions are Public Education Centers in bound of general directorate.

The most significant baseline of adult education in Turkey is the Regulation of Public Education Institutions (RPEI) dating 14.02.2006. This regulation organizes and regulates the methods and principles about the organization, task and operation of common public education institutions together with the methods and fundamentals related to management, education, production, guidance and supervision of the courses that will be opened off the regulation of private education institutions under the supervision or cooperation of public education centers. Besides, RCPEI determines the organization, task, management, education, production, guidance, supervision and coordination functions and processes of public education centers and educational chambers together with the methods and fundamentals related to permission, confirmation, education, supervision and guidance that will be opened off the regulation of private education institution, by other formal and private institutions and organizations, municipalities, occupational institutions, associations, foundations and voluntary organizations under the supervision or cooperation of public education centers.

It is inevitable that adult education activities, which manage such a critical objective, are performed regularly. Just like in every professional action, the fact that adult education activities and events are operated in accordance with management processes not only leads up to reach the determined aims in a healthier way but it also contributes to adults in learning. Management processes are defined as 'all the activities related to activating the structure of the organization with a particular method in order to reach the aim'. Management is a relatively complex task. So as to investigate management, it is a necessity to analyze management process (Lunenberg \& Ornstein, 2012). To be able to mention about management, management process should have certain features. Kochhar (1997) defines these features as; management should be a group activity; management should have a humane property; management should be a corporation and specialization process; management should be a coordination process and management should be an orientation process. Together with the fact that different writers have classified management processes in different ways when literature is analyzed, the aim of this study is to analyze adult education system in Turkey within the framework of management processes; decision making, planning, organizing, communication, coordination, affection and evaluation; and from the point of public education centers' directors where adult education activities are organized in the most intense way.

\section{Method}

In this part, within the context of research method, the information is given about the model of the research, study group, data collection tool and data analysis.

\subsection{Research Model}

This research, which is done so as to define the views of public education center administrators related to the management process of adult education activities, is phenomenological method, which is one of the qualitative research techniques. Data of the research is collected via interview, which is one of data collection techniques of quantitative research (Goertz \& Mahoney, 2012; Kuş, 2003). Interview is prepared in order to the information from different people by directing into similar topics (Yıldırım \& Şimşek, 2008). Generally four kinds of interview is mentioned in the literature; structured, semi-structured, unstructured and focus group interviews (Balc1, 2005; Ekiz, 2009; Yıldırım \& Şimşek, 2008). In this research, semi-structured interview technique is used. In semi-structured interviews, by sticking to the subject or field prepared before, researcher feels free to both ask the questions prepared beforehand and ask additional questions in order to get more detailed information about these questions (Büyüköztürk, Kılıç, Akgün, Karadeniz, \& Demirel, 2010; Yıldırım \& Şimşek, 2008). Thus, researcher may add new questions in accordance with the flow of the interview or may not ask some other questions if the participant have given answers while answering the previous questions (Türnüklü, 2000). Within this context, the views of public education center administrators related to the management process of adult education activities are determined via interview and evaluated.

\subsection{Study Group}

The study group of the research is composed of 17 administrators of public education centers in a city located in Aegean Region of Turkey. When Table 1, which includes the data about the administrators forming the study group is analyzed, it is concluded that the administrators of public education centers are mainly class teachers. It can be seen that administrative length of service of administrators range from 3 to 20 years; while their occupational length of service range from 9 to 25 years. 
Table 1. Data related to public education center administrators

\begin{tabular}{|c|c|c|c|c|}
\hline Administrator & Duty & Field of Teaching & $\begin{array}{c}\text { Administrative Length } \\
\text { of Service } \\
\text { (year) }\end{array}$ & $\begin{array}{c}\text { Occupational Length } \\
\text { of Service } \\
\text { (year) }\end{array}$ \\
\hline A1 & Administrator & Social Studies & 20 & 25 \\
\hline A2 & Administrator & Class Teacher & 5 & 13 \\
\hline A3 & Administrator & Class Teacher & 6 & 12 \\
\hline A4 & Administrator & Class Teacher & 3 & 9 \\
\hline A5 & Administrator & Class Teacher & 9 & 14 \\
\hline A6 & Administrator & $\begin{array}{l}\text { Religious Culture and } \\
\text { Moral Knowledge }\end{array}$ & 5 & 12 \\
\hline A7 & Administrator & Class Teacher & 5 & 16 \\
\hline A8 & Administrator & Class Teacher & 2 & 13 \\
\hline A9 & Administrator & Social Science & 1 & 14 \\
\hline A10 & Administrator & Class Teacher & 4 & 9 \\
\hline A11 & Administrator & Class Teacher & 9 & 14 \\
\hline A12 & Administrator & $\begin{array}{l}\text { Religious Culture and } \\
\text { Moral Knowledge }\end{array}$ & 5 & 12 \\
\hline A13 & Administrator & Class Teacher & 5 & 16 \\
\hline A14 & Administrator & $\begin{array}{l}\text { Religious Culture and } \\
\text { Moral Knowledge }\end{array}$ & 1 & 8 \\
\hline A15 & Administrator & Office Management & 6 & 15 \\
\hline A16 & Administrator & Class Teacher & 5 & 12 \\
\hline A17 & Administrator & Class Teacher & 4 & 11 \\
\hline
\end{tabular}

\subsection{Data Collection Tool}

In the research, data is collected by semi-structured interview form. First of all, in order to prepare the interview form that was used to identify the views of public education center administrators related to the management process of adult education activities, literature and regulation review were made. Interview form is constituted based on literature and related regulations. So as to check whether the interview form is appropriate for the objective, comprehensible and applicable, the views of four academic members from the field of educational management and supervision are asked for. According to the feedback, necessary revisions were made, pre-interviews were made with two administrators and the final shape was given to the form.

The interview form, which was prepared focusing on putting forth the views of the participants about the management of adult education activities, includes questions related to; how the decisions about adult education activities are made; how the planning process of these activities is formed; how the needs in educational activities such as teaching materials, curriculum, resources, classrooms are met; how the public, participants and tutors are communicated with during educational activities; who and what institutions are cooperated during the process of educational activities; by using what ways the participants and administrators are motivated in order to perform adult education activities more efficiently; and how adult education activities are evaluated.

\subsection{Data Analysis}

The administrators of the institutions who participated in the research were interviewed for almost one hour each by the researcher. Besides, by getting the permissions of the administrators these interviews were recorded. The data gathered were analyzed via content and descriptive analysis method. As mentioned by Creswell (2007), in accordance with phenomenological research design, the data gathered was listened for a few times and necessary notes were taken before content and frequency analysis, and the data was divided into meaningful sections as sentences or words. What each of the section meant conceptually was attempted to be found out and these sections which formed a meaningful whole in itself were named and coded. After all the data was coded, a code 
list was constituted. By analyzing the data gathered and by giving the same codes to the data with similar meanings in different sections, concepts were formed. In order to decrease the internal validty of the research, another specialist in the field of educational administration was asked to code the data. By this way, Miles and Huberman's (1994) 'Interrator percentage $(\mathrm{p})=$ [Interrator Aggreement $(\mathrm{Na} /($ Inrerrator Disaggrement $(\mathrm{Nd}))] \mathrm{x}$ 100 ' formula was used to calculate the agreement between the codes. According to this formala, the aggreement percentage between various two coding was determined as \%90. Later on, by getting the meaningfully relational concepts together in the same category in accordance with the research questions, they were placed under the themes defined before the analysis as; 'adult education in decision-making process', 'adult education in planning process', 'adult education in organization process', 'adult education in communication process', 'adult education in coordination process', 'adult education in affection process' and 'adult education in evaluation process'.

\section{Results}

In this section, the findings gathered from the views of the public education centers' administrators related to the management processes of adult education activities are given.

\subsection{Findings Related to the Evaluation of Adult Education Activities in Terms of Decision Making Process}

The question of how the decisions related to programs applied in public education centers are made and what processes these decisions pass through has been asked to 17 administrators in charge of public education centers. It is understood from the answers of the administrators that the decisions made in terms of the educational programs organized in public education centers are shaped according to three variables. As can be seen in the sub-themes given in Table 2, these decisions are made in accordance with 'needs of trainees', 'modules/programs defined by the ministry' and 'demands of individuals responsible for education'.

Table 2. Theme of adult education in decision making process

\begin{tabular}{llc}
\hline Sub Theme & \multicolumn{1}{c}{ Code } & Frequency \\
\hline \multirow{3}{*}{ Needs of Trainees } & Needs related to personal development & 11 \\
& Needs related to getting a profession & 6 \\
& Needs based on test preparation & 5 \\
\hline \multirow{2}{*}{ Modules/Programs Defined by the Ministry } & Most preferred modules/programs & Modules/Programs considered appropriate to be \\
& opened & 7 \\
\hline Demands of Individuals Responsible for & Trainer demands & 4 \\
Education & Administrator demands & 4 \\
\hline
\end{tabular}

In accordance with the responses the administrators have given, it can be seen that the first sub-theme of 'Adult education in decision making process' theme is 'Needs of trainees'. The codes of this sub theme are 'needs related to personal developmen', 'needs related to getting an occupation' and 'needs based on test preparation'. It is put forward that the needs of the trainees are determined in accordance with the interviews of the administrators with local people and the questionnaires the employees of the institution apply to them. The answers that the administrators give show that the most significant factor which affects decision making related to educational programs to be opened is the needs related to personal development. Areas such as folk dances, art and foreign language that local people pay attention to as personal development are seen to be effective on the decisions to be made with regard to the courses to be opened. Some of the responses that center administrators have given related to this category are as follows;

A7: "The reasons of the trainees to apply are very different. This directly affects our decisions. However, our trainees generally pay more attention to personal development. Especially older people aspire more than younger ones. At local cafes, most of the older mentioned that they want to learn new things."

As a result of the interviews, it can be seen that another category of 'needs of trainees' sub theme is 'needs related to getting an occupation'. Administrators have indicated that trainees want to participate in the courses or demand courses appropriate for the skills determined by the organizations to be able to be employed in these organizations. They express that the trainees want to get certificates in web design, furnace stoker, and natural gas use fields initially and they demand courses so as to be employed. The response of one of the administrators 
about it is as follows;

A12: "There are various programs but our centers are also vocational course centers. Individuals come and get a web design certificate and get a job via this certificate. Others get furnace stoker certificate and then find jobs in a residential site. As you can understand, our course decisions are affected by these situations."

The interviews made with the administrators put forth the fact that another point that affects the decisions to be made related to the programs to be opened is 'needs based on test preparation'. The administrators express that especially young adults demand courses related to the tests they will take especially on such areas as math's, foreign language, computer, rhetoric and diction. One of the administrator's view on this topic is as follows;

A15: "We've got trainees of all ages. Not all of them are adults. We have kids and young people. The students cannot have private courses because they are expensive. They join courses of all subjects in our center and they have the opportunity to get prepared for the tests. There are students and adults who want to get prepared for the national tests and they demand courses."

The administrators of the centers have also indicated that they are in favor of opening courses in accordance with the specialty fields of the individuals from different regions together with their individual and occupational needs and that these individuals come up with these demands. It can be seen that specialists of such fields as bee keeping, olive feeding, folk dances, marbling art, tailoring who are professionals of their fields and who prove their specialty via their certificates apply to be able to open courses, and the administrators of the centers evaluate these demands according to the needs of the local people and the conditions of the centers. In addition to this, the administrators also demand the same from the experts. The view of one of the administrators on this topic is as follows;

A8: "As administrators, we need to think twice about opening what course will be better for local people. I personally emphasize my own demands in the committees and request my colleagues to set up operations towards these courses."

In accordance with the responses that the administrators have given, it can be seen that the second sub theme of 'Adult education in decision making process' is 'Modules/Programs determined by the ministry'. The administrators indicate that the exact bounder about the courses planned to be opened is the modules/programs determined by the ministry. It is understood that General Directorate of Lifelong Learning which operates connected with Ministry of National Education is the exact bounder of these modules/programs on the basis of the needs of the region, demand of public and their own preferences. The statement of an administrator related to modules/programs determined by the ministry is as follows:

A5: "Every program opened in public education centers are determined by General Directorate of Lifelong Learning. When you click on the website, you will see it. Every program has a framework plan. We, as administration, determine our preferences about the courses in accordance with this list."

\subsection{Findings Related to the Evaluation of Adult Education Activities in Terms of Planning Process}

The evaluation of adult education activities in terms of management processes continues with the findings related to planning process. In this section, the administrators of public education centers are asked questions about how planning process of adult education programs are determined and which activities this process includes. According to the analyses made after the responses given by the administrators of the centers, there are two sub-themes of 'Adult education in planning process' theme as 'Forming planning commission' and 'Determining planning criterions', and they are given in Table 3.

Table 3. Theme of adult education in planning process

\begin{tabular}{llc}
\hline Sub Theme & Code & Frequency \\
\hline Forming Planning & Forming commission by the assignment of the center directorate & 11 \\
Commission & Forming commission according to specialty & 8 \\
\hline $\begin{array}{l}\text { Determining Planning } \\
\text { Criterions }\end{array}$ & $\begin{array}{l}\text { Determining criterions in accordance with the contents of } \\
\text { educational programs }\end{array}$ & 7 \\
\hline
\end{tabular}

As a result of the responses given by public education center administrators, it is concluded that the first sub-theme is 'Forming planning commission' and this sub-theme includes two categories as 'Forming 
commission according to specialty' and 'Forming commission by the assignment of the center directorate'. For the first category, the administrators have indicated that planning related to the courses to be opened are determined in accordance with the trainers who will give the courses and their specialties. Besides, they have expressed that they are making plans in accordance with the criterions of Lifelong Learning General Directorate and the trainees' demands and needs. The view of an administrator about this category is as follows:

A11: "Planning the courses to be opened is really significant. If you do not make good plans, you can experience problems during the courses. For example, I demand to form the commission just before the courses are opened. I have the trainers get together. I even participate in some of the meetings and try to see what we have. The trainers determine aims and objectives in these planning commissions. Also, they need to develop alternatives for the estimated problems."

Together with the planning commissions determined in accordance with specialty, there is another category of this sub theme as 'Forming commission by the assignment of the center directorate'. The administrators have indicated that when the experts are busy or the trainers have not yet been determined, they form the commissions themselves and these commissions make planning in accordance with the criterions determined by the ministry and the needs and demands of the trainees applied for educational programs. The view of an administrator related to 'Forming commission by the assignment of the center directorate' category is as follows:

A17: "Decision making is important but planning is more important. I have planned private life also. I want the courses to be planned in advance. If we have decided about the course, I have the friends in the center get together and let them start the commission. Later on, I want the reports of the plans."

The following sub-theme of Adult Education in Planning Process theme is 'Determining Planning Criterions'. Related to this sub-theme, public education centers' administrators have indicated that following the decisions made with regard to educational programs to be opened as a result of the modules of Lifelong Learning General Doctorate, demands of the public and their own evaluations, planning commissions are formed and these commissions determine the content criterions of every course. Together with the fact that these criterions are different from each other, they are seen to be important by the administrators in terms of the functionality and sustainability of the educational programs. The reason for this is that the duration of these programs is not short and it is necessary to make plans for each of them. The statement of an administrator related to this sub theme is as follows:

A1: "We are in contact with other administrators about the planning processes. Our commissions are able to predict about the future within the framework of these criterions."

\subsection{Findings Related to the Evaluation of Adult Education Activities in Terms of Organization Process}

The evaluation of adult education activities in terms of management processes continues with the findings related to organization process. As a result of the answers to the questions asked the administrators of public education centers about how such needs as trainer-material-curriculum-classroom of educational programs developed are met, the theme of 'Adult Education in Organization Process' has been formed. As shown in Table 4., this theme is composed of 4 sub themes as 'determination of the trainers', 'determination of educational materials', 'determination of the curriculum' and 'determination of the classrooms'.

Table 4. Theme of adult education in organization process

\begin{tabular}{llc}
\hline Sub Theme & Code & Frequency \\
\hline \multirow{2}{*}{ Determination of the trainers } & Trainers determined by central administration & 12 \\
& Demands of field specialist & 6 \\
\hline $\begin{array}{l}\text { Determination of educational } \\
\text { materials }\end{array}$ & Materials determined by the trainers & 15 \\
\hline \multirow{2}{*}{ Determination of the curriculum } & Materials determined by central administration & 4 \\
\hline \multirow{2}{*}{ Determination of the classrooms } & Curriculum determined by general directorate & 17 \\
& Curriculum determined by the trainers & 5 \\
\hline & Classrooms which belong to central directorate & 13 \\
& Classrooms requested from other institutions and & 9 \\
\hline
\end{tabular}


The results of the analysis of the responses of the administrators given under the sub-theme of 'Determination of trainers has been divided into two categories. About 'the demands of field specialists', by taking the demands of competent and certified trainers and the needs of the region into consideration, the administrators have indicated that within the very beginning of each educational year they open courses accordingly and some part of trainers' needs of the programs are met to an extent. As can be understood from the name of 'Trainers determined by central administration', not only the trainers of the courses determined by Lifelong Learning General Directorate but also the ones determined by central administration are given by the ones provided by the central administration. The statement of an administrator related to this sub theme is as follows:

A4: "Determination of the trainers is really important because we would like to work with hardworking people. When the trainer is hardworking, the trainees are satisfied, too. That's why, when we have demands from the trainers about opening courses. As an administrator, I totally believe that a person who wants to open a course will do his/her work in the best way."

It has been concluded that the other sub-theme of the theme of 'Adult Education in Organization Process' is 'determination of educational materials' and the codes are 'the materials determined by the trainers' and 'materials determined by central administration'. The administrators have indicated that most of the materials are determined by the trainers. The reason of this is that the trainers are the experts of their fields and they decide what material they need for the course. However, the administrators have also stated that when the find the trainer themselves and when the course is dictated by the central administration, they find it difficult to determine the materials. In such occasions, the materials are decided by central administration. One of the administrator's statement related to this sub theme is as follows:

A6: "The trainers decide about what material they need for the course. They are the experts. They know better what the best is for the content of the course. Most of the trainers are the ones that have given classes at our center before, so their materials are already ready."

Another sub-theme of the theme of 'Adult Education in Organization Process' is 'determination of the curriculum'. This sub-theme has two codes as 'the curriculum determined by general directorate' and 'curriculum determined by central administration'. The administrators of public education centers have expressed almost the same view about the determination of educational programs' curriculum. All of the administrators state that the curriculum is determined by general directorate before each semester starts and some of the administrators have indicated that in addition to general directorate, trainers contribute to curriculum development. The view of an administrator is as follows:

A2: "Topics and contents are sent to us by general directorate but we give our trainers freedom about that. On the condition that they stick to general framework of general directorate and teach the trainees the necessary topics, they are able to determine the content of the course."

As a result of the analysis, the last sub-theme of this section is 'determination of the classrooms'. To the question of where the courses are given, the administrators have responded that most of the time the educational programs are performed in the classrooms of public education centers. However, some administrators have stated that sometimes their classrooms are not enough for the courses. As mentioned in coordination process, they have expressed that they coordinate with other institutions and organizations, and sometimes they use the classrooms of the schools of Ministry of National Education without interrupting the school program. The view of an administrator on this topic is as follows:

A16: "Our courses are given in the classrooms of our center. We make great effort to get the physical conditions of our classrooms ready for the courses. As an administrator and as a teacher, I am totally aware of the direct impact of the classroom's physical condition on the quality of the lesson."

\subsection{Findings Related to the Evaluation of Adult Education Activities in Terms of Communication Process}

The administrators have been asked questions related to the communication channels they develop with the public, trainees and trainers with regard to the management of the evaluation of adult education programs in terms of communication process. As can be seen in Table 5, the findings of this section is given under the theme of 'Adult Education in Communication Process'. As a result of the interviews made, it can be seen that this theme is composed of three sub-themes as 'Communication with the public', 'Communication with the trainees' and 'Communication with the trainers'. 
Table 5. Theme of adult education in communication process

\begin{tabular}{llc}
\hline Sub Theme & Code & Frequency \\
\hline \multirow{3}{*}{ Communication with the public } & Trainers and previous trainees & 8 \\
& Use of billboards & 7 \\
& Newspaper advertisements & 2 \\
\hline \multirow{2}{*}{ Communication with the trainees } & Use of telephone & 17 \\
& Use of e-mail & 9 \\
\hline \multirow{3}{*}{ Communication with the trainers } & Formal notification & 17 \\
& Use of telephone & 17 \\
& Use of e-mail & 9 \\
\hline
\end{tabular}

In the responses the administrators have given about the sub-theme of 'Communication with the public', they indicate that the most important factor to be able to open courses is to announce the public and give enough information about the courses. The administrators, who state that it is the prior duty of the trainers and previous trainees to be able to provide this, think that the two elements to announce the success of the courses to public are these two groups. They also express that they have advertisements of the courses via posters, announcements and billboards which are set to places where people mostly spend time. Several administrators state that in addition to all these mentioned above, they give info news and advertisements about the educational programs to be opened to local press and especially to local newspapers followed by local shopkeepers. The view of an administrator related to the sub theme of 'Communication with the public' is as follows:

A13: "Communication is really important for us. We need to communicate with our potential, new and previous trainees. The most important way of reaching our potential trainees is may be, the announcement of the courses to be opened or the information given by our previous trainees and trainers. That's why we text them about the courses to be opened."

It is put forward as a result of the interviews with the administrators that another sub-theme of "Adult education in communication process' is 'communication with the trainees'. The administrators have stated that they communicate with them via text message initially and then via e-mail. To the question of on what conditions they use these communication devices, the administrators have responded that they inform the trainees via text message when the course is postponed, when there is an instant change or a timetable change, and that the usual notifications are made via e-mail. One of the responses the administrators have given related to this sub theme is as follows:

A5: "When the trainees apply for a course, we get their contact info together with personal info. We use these information during the course. There can be last minute situations. For example, our trainers amy have things to do and they may not come that day. We immediately inform our trainees via text messages."

It can be understood from the interviews made with the administrators that the last sub-theme of 'Adult education in communication process' is 'communication with the trainers' and the codes of this sub theme are 'formal notification', 'use of telephone' and 'use of e-mail'. All of the administrators have stated that the trainers have continuously been informed about all the incidents via formal notification. In addition to this, they are called in such situations as course cancellation or a change in date or time of classes immediately. Some of the administrators have expressed that the trainers are informed about both general and immediate announcements via e-mail. One of the responses the administrators have given related to this sub theme is as follows:

A10: "Our communication with the trainers starts with formal notifications. Most of our trainers are teachers working at the schools of Ministry of National Education. They are tasked after formal notification. This is the rule. They are of course informed about the course but they get this formal paper anyway."

\subsection{Findings Related to the Evaluation of Adult Education Activities in Terms of Coordination Process}

In this section of the research, the findings gathered about the question of whether central administrations coordinate with other institutions or organizations during the operation process of educational activities are given. The findings reveal that they benefit from coordination process. As can be understood from Table 6., as a result of the interviews with the administrators of the centers, the theme of 'Adult Education in Coordination Process' has been put forward, and this theme contains the sub-themes of 'Coordination with State Institutions and 
Organizations' and 'Coordination with Non-governmental Organizations'.

Table 6. Theme of adult education in coordination process

\begin{tabular}{llc}
\hline Sub Theme & Code & Frequency \\
\hline \multirow{3}{*}{ Coordination with State Institutions and Organizations } & Coordination about Classroom Necessity & 8 \\
& Coordination about Trainer Necessity & 7 \\
& Coordination about Material Necessity & 4 \\
\hline \multirow{2}{*}{ Coordination with Non-governmental Organizations } & Coordination about Material Necessity & 8 \\
& Coordination about Curriculum & 5 \\
\hline
\end{tabular}

As can be seen in Table 6, the sub theme of 'Coordination with State Institutions and Organizations' is composed of three codes as 'Coordination about Classroom Necessity', 'Coordination about Trainer Necessity' and 'Coordination about Material Necessity'. According to the views of the administrators, they coordinate with Ministry of National Education when they need classrooms, trainers and materials. They also state that first of all they try to meet these necessities themselves and after that they demand from the ministry. Similarly, they are involved in the coordination process when sate schools want to open courses within public education centers. The view of an administrator related to this is as follows:

A9: "Coordination is really important in every work but when education is the matter, it becomes more important. Our most significant problem is classrooms. Mostly, were have trouble finding enough classrooms and first, we ask the schools of the ministry. Luckily, they give us the classrooms after formal education. but of course this is reciprocal. We also organize courses demanded to be opened at school and take on the responsibility."

The other sub-theme of 'Adult Education in Coordination Process' theme is 'Coordination with Non-governmental Organizations'. The administrators have indicated that when non-governmental organizations demand courses within the standards of Lifelong Learning General Directorate, they treat positively and try hard to give the desired educational programs. The statement of and administrator related to this is as follows:

A2: "The offices of some non-governmental organizations demand courses for their members. Approved by general directorate, we make an effort to be able to open these courses. Generally, these courses are about personal development. They are successful and the trainees are mostly satisfied."

\subsection{Findings Related to the Evaluation of Adult Education Activities in Terms of Affection Process}

Another finding of the research, which aims to evaluate Turkish adult education system in terms of management processes, is affection process. The administrators of public education centers have been asked the question of whether they use affection and motivation tools towards the trainees and trainers for better educational process and if they do, what kind of tools they use. According to the responses given by the administrators, the theme of 'Adult Education in Affection Process' has been put forward. The sub-themes of this main theme is 'motivation of trainees' and 'motivation of trainers'.

Table 7. Theme of adult education in affection process

\begin{tabular}{llc}
\hline Sub Theme & Code & Frequency \\
\hline & $\begin{array}{l}\text { Final activities performed at } \\
\text { the end of the courses } \\
\text { Prompting by the trainers } \\
\text { continuously towards the } \\
\text { importance of the course } \\
\text { Prompting by the } \\
\text { administrators continuously } \\
\text { towards the importance of the } \\
\text { course }\end{array}$ & 7 \\
\hline
\end{tabular}




\begin{tabular}{lll}
\hline Motivation of trainers & $\begin{array}{l}\text { Paying the trainers' wage on } \\
\text { time } \\
\text { Meeting necessities }\end{array}$ & 8 \\
\hline
\end{tabular}

As can be seen in Table 7, 'motivation of the trainees sub theme' involves the codes of 'prompting by the trainers continuously towards the importance of the course', 'prompting by the administrators continuously towards the importance of the course' and 'final activities performed at the end of the courses'. It can be concluded as a result of the interviews with the administrators that they give importance to affection process. The administrators see final activities as the initial motivation tool and they emphasize that the trainees enjoy a lot in these activities. Besides, they state that both they themselves and the trainers emphasize the importance of the courses and they keep themselves active so as not to let the trainees break out. One of the views of the administrators related to this is as follows:

A16: "You should prompt the people if you are doing something with them. Our task is motivating the people continuously just like a manager of a football team. We often talk this with our trainers. We know that if the trainees believe the importance of an educational programme, they are more successful and the classes are efficient. Our trainers prompt the trainees continuously during the classes and thus, attendance arises."

The other sub-theme of 'Adult Education in Affection Process' theme is 'motivation of trainers'. It is seen that this sub theme is composed of two codes as 'paying the trainers' wage on time' and 'meeting necessities'. The administrators have indicated that the trainers should also be motivated for healthier educational activities. So as to motivate the trainers and make them do their jobs willingly, they make great effort to pay their wages on time and meet such necessities as material, curriculum, etc. One of the views of the administrators related to this is as follows:

A3: "It is not always easy to find trainers. As I said before, most of them are teachers working for state schools. Others have got other tasks to do. Every job has a retribution. More or less, we pay the trainers for working here. Our trainers are really important for us so we try to pay them on time."

\subsection{Findings Related to the Evaluation of Adult Education Activities in Terms of Evaluation Process}

The last findings of the research are about dealing with the analyses of educational programs in terms of evaluation process. The administrators of public education centers have been asked whether evaluation of educational programs is made; if yes, when, according to what criterions and by whom this evaluation is made. As a result of the responses given, the theme of 'Adult Education in Evaluation Process' is put forward. This theme is seen to have two sub-themes as 'Evaluation made by the trainers' and 'Evaluation made by central administration'.

Table 8. Theme of adult education in affection process

\begin{tabular}{llc}
\hline Sub Theme & Code & Frequency \\
\hline \multirow{2}{*}{ Evaluation made by the trainers } & Tests done during the educational program & 17 \\
& Tests done at the end of the educational program & 17 \\
\hline \multirow{3}{*}{ Evaluation made by central administration } & Meetings by central administration & 17 \\
& Meetings with the trainers & 9 \\
& Interviews with the trainees & 6 \\
\hline
\end{tabular}

As can be seen in Table 8., 'Evaluation made by the trainers', which is the first sub-theme of the theme of 'Adult Education in Evaluation Process' includes two codes as 'tests done during the educational program' and 'tests done at the end of the educational program'. According to the views of the administrators, the trainers evaluate the improvements of the trainees during and at the end of each course via different measurement tools. The view of an administrator which states that these evaluation tools are prepared by the trainers is as follows:

A7: "We don't want the educations to be finished immediately or just to be something as formality. We put evaluation elements into practice with regard to our education programs. Our trainers do evaluation tests at the end of each course and thus, we can see how much our trainees have benefitted from our programs." 
The second sub-theme of 'Adult Education in Evaluation Process' theme is 'Evaluation made by central administration'. The codes of this-sub theme are 'Meetings with the trainers', 'Meetings by central administration' and 'Interviews with the trainees'. The administrators have implied that they have given more importance to evaluations in the recent years. The reason for this is the organizational structure of Lifelong Learning General Directorate and the expectation of the directorate about evaluation. They have also stated that at the end of each course, the trainers come together for evaluation, and then the center administration organizes evaluation meetings, and as much as possible, they come together with the trainers, do interviews with them evaluate the courses both during and at the end of each course. The view of an administrator related to this is as follows:

A17: "At the end of each course, we need to organize evaluation meetings and we do. I'm aware of its importance. Especially, I want to get together with the teachers I want to learn how the course went on and if there were any problems, and I get their suggestions. We have spent a lot of time on this for a few years and we benefit from this."

\section{Conclusion, Discussion and Suggestions}

In this study, the views of public education centers' administrators on the management processes of adult education programs are analyzed. Scanlon (2009) has indicated that the concepts of lifelong learning and public education express an obligation within the framework of necessities for individuals. This situation arises from the expectations of the new conditions of the changing world. That's why, most adults return back to education because they do not see their qualifications enough. Beblavy, Thum, and Potjagailo (2014) have implied that besides the global perspective to adult education in literature, adult education is among the most important educational policies in Europe, and together with increasing population and with the impact of new employment areas, the individuals lionize on participating in adult education. In addition, Miser, Ural and Ünlühisarıklı (2013) state that although the background of education is old, it is not yet at a desired level. In spite of the fact that most of the participants of adult education programs which are managed by Ministry of National Education are young adults, more than half of whom are males, have low levels of literacy with only primary school education, it is not at a desired level. This situation makes it obligatory to evaluate the management dimension of adult education system and its evaluation in terms of management processes.

The administrators of public education centers in which adult education programs are organized have given their views about what decisions are made by following what steps. When the answers of the administrators are analyzed, it can be concluded that these decisions are made by taking into account the needs of the trainees, the standards determined by Lifelong Learning General Directorate and the demands related to educational programs. The views of center administrators in terms of decision making process show that this process is mostly organized by the administrators themselves. They indicate that they think multi-dimensionally, take every alternative into consideration and believe the importance of opening the most beneficial course for the participants. They consider decision making from a technical point of view and listen to their trainers during decision making process, and in accordance with this, aim to prevent future problems. Also, they state that they make visits in the region so as to be able to collect information because they believe that the correct decision can only be made after collecting enough information. When the general structure of adult education programs are taken into consideration, meeting the needs of our era and of the trainees are some part of the decisions made. In spite of all these, the standards and course contents determined by general directorate seem to hinder the centers to make independent decisions. It can only be prevented by taking both their own and the trainers' demands into account, giving particular importance to the needs of the trainees and opening not only occupational but also personal development courses. Aksakal and Kozu (2015) states that together with the fact that adult education gives the individuals new information fields, opportunities and the necessary self-confidence, it will also contribute the education of the people around. That's why, while making decisions related to adult education activities, there must rational decision making and the adults must be given the opportunity to reflect the education to their families and people around.

Planning process of adult education programs can be put forward by means of the views of the administrators. They have stated that planning process is performed not only by the commission professionally but also within the framework defined in advance. The administrators who state that planning process is not a task of only themselves indicate that the trainers should also be involved in the process. Not only are the views of the administrators a step to prevent problems that can be encountered during educational programs, but they also let the centers foresee the opportunities and risks. Despite the fact that benefiting from specialty field while forming planning commissions is a great factor in the success of planning process and educational programs, it is a high possibility that there will be problems arising from the fact that the commissions formed by the administration of 
the center from the employees of the center lack the necessary knowledge and experience. The reason for this is the evaluation of the data and determination of the objectives can only be provided by the administration and field specialists. It can be understood from the responses of the administrators that planning is only made at the very beginning and is not handled as a process. However, planning is a dynamic process and can be flexible. The steps taken at the beginning of the planning process can predict future to a certain extent. Nonetheless, not extending the process to every phase of educational programs can be the start of all administrative problems. Illeris (2016) states that lifelong learning and adult education have been one of the most important agendas of the nations, educational policies of the governments, investors, companies and non-governmental organizations. This brings together an increase in the number of adult education programs and participants. That's why, planning process of adult education activities have been more important than ever before. In adult education management, not only short-term plans but also medium and long term plans should be taken into account and all the elements of planning process should be activated.

The conclusions of the organization process of the research in which it is aimed to evaluate adult education programs in terms of management processes put forth the fact that the administrators fulfill all the essentials of organization process. It is obvious that the administrators interviewed make all the necessary efforts to decide about the trainers, supply materials, prepare curriculum and provide classrooms. They state that not only do they decide the trainers themselves which is the main element of educational programs, but also take the demands of field specialists into consideration. Accordingly, they do not put forth their own criterions in determining materials and curriculum only, but they also take into account the suggestions of both the field specialists and general directorate. These applications can be important steps to minimize educational problems that could be encountered during education process. Another proof of professional organization process is that during this process, coordination process is also performed and they have worked together with other institutions and organizations to be able to provide classrooms. Cachioni et al. (2014) state that renewal and update of knowledge is essentially significant in modern societies so as to be able to let the individuals spend the rest of their lives efficiently. In his study, the same writer emphasizes that educational opportunities of our age present adults important opportunities in order to make them efficient for their future and coming together in adult settings enables the adults to face similar problems and find solutions together. The elements of organization process and the distribution of tasks and responsibilities is a process which should be sensitively taken into consideration in adult education.

Including all the shareholders in communication process during adult education programs can be understood from the statements of the administrators. It is obvious that being in communication with potential trainees, present trainees and trainers via various communication tools contributes to healthier educational periods. It is certain that using such communication tools as billboards, newspaper adverts, phones and e-mails has an important role in operating this period effectively. Cincinnato, Wever, Keer, and Valcke (2016) state that one of the factors that affects the adults' participation in education programs and their perspective to lifelong learning phenomenon is their social background and perspective to education. Educational statuses of the individuals' family and their educational gains have great impact on their readiness and all these factors provide a perception in terms of participating in these educational activities. This shows itself in communication with the individuals without formal education or with an incomplete education. Especially in communication with these individuals and in the communication tools used, there should be extra importance in terms of both trainers and management, and they should also be communicated and told the importance of education verbally.

The information that public education center administrators share about coordination process shows that this process is composed of two dimensions as governmental and non-governmental organizations and institutions. Coordination process, which is especially performed with both groups with regard to educational programs, put forth what problems all the public education centers experience and on what topics they need to be supported. The centers which are obvious to experience problems especially about classrooms, trainers and material perform coordination activities in order to be able to meet these necessities. According to McGivney (2004), as in all levels, also in adult education there is student abandonment. The reasons for this situation are personal factors, availability of education, differences arising from gender, lack of family or peer support, financial problems, factors about the educational institution, time problem and lack of motivation. One of the most important of these factors is the problem experienced during guidance and instruction. When the period and perspective to education are taken into account, it can be said that the management of adult education differs from that of formal education. Coordination process, which is managed with regard to financial and physical necessities only, should be performed together with different individuals and institutions in guidance and instruction dimensions so as to be able to make every adult complete his education at the most efficient level. 
In affection process, which is one of management processes, it can be concluded that the administrators of public education centers make great effort to be able to make the program operate effectively by using motivation techniques for both the trainees and the trainers. It can be seen that by prompting the trainees and organizing union activities, the administrators motivate them about the programs. Together with this, they pay attention to raise the enthusiasm of the trainers by meeting their educational necessities and doing their payments on time. However, it can be stated as a conclusion of the study that the answers of the administrators in affection process focuses only on the trainers and trainees, and the other staff in the centers are not mentioned. Neagu (2014) states that there are many factors that affect people to participate in the educational programs. In his research, it is indicated that it is essential for the individuals without formal education to participate in lifelong learning activities. In addition, they have to be encouraged and their needs have to be met during educational processes. All these focuses on the importance of affection in adult education and this puts forward the significance of motivation tools in the efficiency of the educational programs. Besides, Boeren, Nicaise, and Baert (2012) emphasizes that certain dimensions of adult education programs and opportunities may create injustice socially in terms of the individuals who didn't have formal education, couldn't be employed and over 45 years old; that's why it is necessary to satisfy the participant so as to be able to provide the efficiency of adult education programs.

The administrators of public education centers whose views have also been taken related to evaluation process, the last of management processes, have indicated that the programs are performed both by themselves and by the trainers responsible for the programs. The administrators have stated that they approach evaluation process professionally; they use process evaluation and evaluate the trainees both during and at the end of the program. Another conclusion which puts forth the point of view of the central administration in terms of evaluation process is that evaluation is made via meetings with the trainers, meetings by central administration and one-to-one interviews with the trainees. Sandberg (2016) emphasizes that the aim of adult education is to support them in both their private lives and professional lives. Besides, he states that adult education is in relationship with such concepts as employment, information society, globalization and lifelong learning. According to Sanberg, this conceptual relation gives a positive meaning to adult education but false applications that can be made will negatively affect the perception of the participants and will cause them not to be able to benefit from the programs appropriately. This situation puts forward the importance of evaluation process. Multidimensional evaluation activities not only at the beginning but also during and at the end of the process are really essential to be able to see the shortcomings and correct them for the following programs.

Considering the whole results, literature and the similar studies, the decisions of the programs planned for the future, first of all, should be handled by a wide analysis of the public and that should be done via different types of assessment instruments. Furthermore, planning commissions of the public education centers should be selected from the people who specialize in education field. Moreover, the results related to the organization of the programs show that public education centers should be supported economically more by the Ministry of National Education and the local governments. Additionally, the results gained in the communication process reveal that the administrators should benefit from the aspects of social media instruments effectively to inform the public about the programs. Lastly, it can be suggested that the public education centers should use more detailed and professional methods to evaluate the programs in order to increase the quality of the training process.

\section{References}

Aksakal, B., \& Kazu, İ. B. (2015). Comparison of Adult Education Policies in Turkey and European Union. Procedia-Social and Behavioral Sciences, 177, 235-239. http://dx.doi.org/10.1016/j.sbspro.2015.02.399

Balc1, A. (2005). Sosyal Bilimlerde Araştırma: Yöntem Teknik ve Illkeler [Reseacrh in Social Sciences: Methods, Techniques and Principles]. Ankara, Pegem Publishnig.

Beblavy, M., Thum, A., \& Potjagailo, G. (2014). Learning at every age? Life cycle dynamics of adult education in Europe. Studies in Continuing Education, 36(3), 358-379. http://dx.doi.org/10.1080/0158037X.2014.918537

Boeren, E., Nicaise, I., \& Baert, H. (2012). Adult learners' satisfaction and its relation to characteristics of the individual and the educational institution. Pedagogies: An International Journal, 7(2), 132-149. http://dx.doi.org/10.1080/1554480X.2012.655887

Büyüköztürk, Ş., Kılıç Çakmak, E., Akgün, Ö. E., Karadeniz, Ş., \& Demirel, F. (2010). Bilimsel Araştırma Yöntemleri [Scientific Research Methods]. Ankara: Pegem Publishing. 
Cachioni, M., Ordonez, T. N., Lima da Silva, T. B., Batistoni, S. S. T., Yassuda, M. S., Melo, R. C., . . Lopes, A. (2014). Motivational Factors and Predictors for Attending a Continuing Education Program for Older Adults. Educational Gerontology, 40(8), 584-596. http://dx.doi.org/10.1080/03601277.2013.802188

Celep, C. (2003). Halk Eğitimi [Public Education]. Anı Publishing, Ankara.

Cincinnato, S., Wever, B. D., Keer, H. V., \& Valcke, M. (2016). The Influence of Social Background on Participation in Adult Education: Applying the Cultural Capital Framework. Adult Education Quarterly, 66(2), 143-168. http://dx.doi.org/10.1177/0741713615626714

Creswell, J. W. (2007). Qualitative inquiry \& research design: Choosing among five approaches (2nd ed.). Thousand Oaks, CA: Sage.

Davison, J. (1967). The contribution of adult education to management education. The Vocational Aspect of Education, 19(44), 208-217. http://dx.doi.org/10.1080/03057876780000251

Duman, A. (2007). Yetişkinler Eğitimi [Adult Education]. Ankara: Ütopya Yayınevi.

Goertz, G., \& Mahoney, J. (2012). A tale of two cultures: qualitative and quantitative research in the social sciences. Princeton, NJ: Princeton University Press. http://dx.doi.org/10.1515/9781400845446

Hamilton, E. (1992). Adult Education for community development (pp. 47-69). New York: Greenwood Press.

Illeris, K. (2003). Adult education as experienced by the learners. International Journal of Lifelong Education, 22(1), 13-23. http://dx.doi.org/10.1080/02601370304827

Jarvis, P. (1987). Adult Learning in the Social Context. London: Croom Helm.

Jarvis, P. (2010). Adult education and lifelong learning: theory and practice (4th ed.). New York: Routledge.

Kochhar, S. K. (1997). Secondary school administration. Sterling publishers private limited. Academic; New Deil-110016, Green park extension.

Kowalski, T. J. (1998). Research and assumptions in adult education: implications for teacher preparation. Journal of Teacher Education, 25(3), 8-10.

Kuş, E. (2003). Nicel-nitel araştırma teknikleri [Quantative and Qualitative Research Methods]. Ankara: Anı Publishing.

Lunenburg, F. C., \& Ornstein, A. O. (2012). Educational administration: Concepts and practices. Belmont, CA: Wadsworth Cengage Learning.

Miles, M. B., \& Huberman, A. M. (1994). Qualitative data analysis: An expande sourcebook. Thousand Oaks, CA: Sage.

Miser, R. (2002). Küreselleşen dünyada yetişkin eğitimi. Ankara Üniversitesi Eğitim Bilimleri Fakültesi Dergisi, 35, 55-60. http://dx.doi.org/10.1501/egifak_0000000054

Miser, R., Ural, O., \& Ünlühisarıklı, Ö. (2013). Adult Education in Turkey. Adult Learning, 24(4), 167-174. http://dx.doi.org/10.1177/1045159513499553

Morgan, R. R., Ponticell, J. A., \& Gordon, E. E. (1998). Enhancing Learning in Training and Adult Education. Westport, Conn.: Praeger.

Neagu, G. (2014). Determinants factors of adult participation in education. Procedia-Social and Behavioral Sciences, 142, 473-480. http://dx.doi.org/10.1016/j.sbspro.2014.07.651

Regulation of Public Education Institutions. (2006). Retrieved from http://mevzuat.meb.gov.tr/html/26080_0.html in 25.03.2015

Sandberg, F. (2016). Recognition and adult education: An incongruent opportunity. Studies in Continuing Education. http://dx.doi.org/10.1080/0158037X.2016.1160881

Scanlon, L. (2009). Identifying supporters and distracters in the segmented world of the adult learner. Studies in Continuing Education, 31(1), 29-43. http://dx.doi.org/10.1080/01580370902741878

Tight, M. (2002). Key concepts in adult education and training. New York, NY: Routledge.

Türnüklü, A. (2000). Ĕgitimbilim Araştırmalarında Etkin Olarak Kullanılabilecek Nitel Bir Araştırma Tekniği: Görüşme [An Effective Qualitative Research Method in Education Sciences: Interview]. Kuram ve Uygulamada Eğitim Yönetimi Dergisi. 24. Ankara: Pegem Publishing.

UNESCO. (1985). Final Report. Fourth International Conference on Adult Education. 19-29 March, Paris. 
Walklin, L. (1990). Teaching and learning in further and adult education. England: Stanley Thornes.

Yıldırım, A., \& Şimşek, H. (2008). Nitel Araştırma Yöntemleri [Qualitative Research Methods]. (7. Baskı). Ankara: Seçkin Publishing.

\section{Copyrights}

Copyright for this article is retained by the author(s), with first publication rights granted to the journal.

This is an open-access article distributed under the terms and conditions of the Creative Commons Attribution license (http://creativecommons.org/licenses/by/4.0/). 